\title{
TATA KELOLA SISTEM INFORMASI PADA PERUSAHAAN PELAYARAN LEPAS PANTAI
}

\author{
Bimo Andono*), Arif Imam Suroso ${ }^{* *}$, dan Ninuk Purnaningsih ${ }^{* * * *}$ \\ *) PT. Cakrawala Andalas Televisi (ANTV) \\ ANTV Epicentrum Studio, Komplek Rasuna Epicentrum Lot.9, Jl. H.R. Rasuna Said, Setiabudi, Jakarta Selatan 12940 \\ ${ }^{* *}$ Sekolah Bisnis, Institut Pertanian Bogor \\ Jl. Raya Pajajaran, Bogor 16151 \\ ${ }^{* * *}$ Departemen Sains Komunikasi dan Pengembangan Masyarakat, Fakultas Ekologi Manusia, Institut Pertanian Bogor \\ Jl. Kamper, Wing 1, Level 5, Kampus IPB Darmaga Bogor 16680
}

\begin{abstract}
This research attempted to audit the domain of planning and implementation of PT BRL Information System (IS) through the determination of Critical Success Factor (CSF), Key Goal Indicator (KGI), Key Performance Indicator (KPI), to measure maturity level and recommend findings and opportunities to the management for the evaluation and improvement in the maturity level of the Information System of PT BRL using the COBIT framework. From the results of this study, the desired direction of PT BRL management can be identified and a number of recommendations can be formulated to realize the plan. IT governance is an important concept that develops in IT companies and acts as a benchmark for measuring the maturity level of IT organizations (Ayat et al. 2011). Overall, the process of planning and implementation of Information System (IS) in PT BRL has followed the rules according to the COBIT framework and its Maturity Level is at the level of 3 -defined where work procedures have been standardized, documented and communicated through the training process. It has also been mandated that this procedure shall be complied with; however, there is still a deviation of procedures that have not been accommodated in their implementation. There are already standardized and well documented procedures as well as formal training to communicate the procedures and policies set up. Nevertheless, the implementation stage still depends on the individuals whether they are willing to carry out the specified procedure or not. The procedures are still limited to the formalization of the existing practices.
\end{abstract}

Keywords: Auditing, COBIT, CSF, KPI, KGI

\begin{abstract}
ABSTRAK
Penelitian ini berusaha melakukan audit pada domain perencanaan dan implementasi Sistem Informasi (SI) PT BRL melalui penentuan Critical Success Factor (CSF), Key Goal Indicator (KGI), Key Performance Indicator (KPI), mengukur maturity level serta merekomendasikan temuan serta peluang kepada pihak manajemen dalam rangka evaluasi dan peningkatan tingkat kematangan Sistem Informasi (SI) PT BRL menggunakan kerangka kerja COBIT. Dari hasil penelitian ini dapat diketahui arah yang diinginkan manajemen PT BRL serta dapat disusun beberapa rekomendasi untuk dapat mewujudkannya. Tata kelola TI adalah konsep penting yang berkembang di perusahaan TI dan bertindak sebagai patokan untuk mengukur kematangan organisasi TI (Ayat et al. 2011). Secara keseluruhan proses perencanaan dan implementasi Sistem Informasi (SI) di PT BRL sudah mengikuti kaidah-kaidah sesuai dengan kerangka kerja COBIT dan Maturity Level-nya berada pada level: 3 -Defined dimana prosedur kerja telah distandarisasi dan didokumentasikan serta dikomunikasikan melalui proses pelatihan. Telah dimandatkan pula bahwa prosedur ini wajib dipatuhi, namun bagaimanapun juga masih ada deviasi prosedur dalam pelaksanaannya yang belum diakomodasi. Sudah ada prosedur yang memiliki standar dan didokumentasikan dengan baik, sudah ada pelatihan formal untuk mengkomunikasikan prosedur dan kebijakan yang dibuat. Namun pada tahap implementasinya masih tergantung pada individu apakah mau melakukan prosedur yang ditetapkan atau tidak. Prosedur yang dibuat masih terbatas pada bentuk formalisasi dari praktik yang ada.
\end{abstract}

Kata kunci: Audit, COBIT, CSF, KPI, KGI

\footnotetext{
${ }^{1}$ Alamat Korespondensi:

Email: bimoandono@gmail.com
} 


\section{PENDAHULUAN}

Keuntungan merupakan hal yang sangat utama dalam bisnis. Selain mencapai pendapatan yang maksimal pengawasan serta fungsi pengendalian pengeluaran merupakan hal yang penting memerlukan perhatian penuh karena kinerja keuangan suatu perusahaan tidak hanya ditentukan oleh seberapa besar pendapatan yang dihasilkan tetapi juga seberapa baik perusahaan mengelola pengeluaran sehingga dapat menghasilkan laba yang optimal bagi pemilik usaha. Tata kelola Teknologi Informasi (TI) mempertimbangkan dua hal, yaitu kemampuan layanan TI atas nilai bisnis dan juga mitigasi risiko TI yang didorong oleh keselarasan strategi TI dengan bisnis serta didorong oleh akuntabilitas organisasi. Kedua faktor tersebut harus didukung oleh sumber daya yang memadai dan diukur untuk menjamin hasilnya (Borousan et al. 2011). PT Baruna Raya Logistics (PT BRL) merupakan salah satu penyedia jasa pelayaran operasional dan logistik lepas pantai yang menyediakan jasa penunjang kegiatan operasional perusahaan migas di Indonesia. Perusahaan migas nasional dan internasional merupakan pelanggan yang menjalin kontrak kerja sama dengan PT BRL. Kapal kerja dalam berbagai jenis dan ukuran disediakan oleh PT BRL untuk memenuhi kebutuhan operasional pelanggan. Naik turunnya pencapaian PT BRL sangat tergantung pada kegiatan operasional perusahaan minyak yang menjadi pelanggannya. Pengelolaan perusahaan akan memiliki risiko yang sangat besar apabila manajemen menjalankan dengan intuisi dan pengelolaan data yang konvensional. Tata kelola TI adalah suatu kapasitas organisasi oleh pimpinan, manajemen eksekutif dan manajemen TI (Grembergen, 2000). Sistem teknologi informasi telah menjadi nyawa bagi setiap industri modern (Adityawarman 2012). Ahmad dan Musa (2009) menyatakan bahwa "Information technology (IT) has become widely integrated into most organizations'. Diperlukan dukungan infrastuktur TI dan Sistem Informasi (SI) yang memadai untuk dapat mendukung manajemen dalam melakukan pengaturan kegiatan operasional, pencatatan, pengelolaan arus kas, monitoring dan kebutuhan bisnis lainnya.

Berawal dari hal ini PT BRL berkomitmen untuk melakukan langkah perbaikan untuk memenuhi kebutuhan akan SI. Berdasarkan beberapa pertimbangan dan rekomendasi maka diputuskan untuk menggunakan salah satu brand Enterprise Resource Planning (ERP) yang terkemuka dan digunakan oleh banyak perusahaan lain, yaitu SAP. Sistem ERP dapat dianggap sebagai alat penting yang dapat meningkatkan operasi bisnis (Tsai et al. 2009).

Bagi organisasi, penerapan TI akan dinilai tepat sasaran jika mampu membuat organisasi melaksanakan tujuan dan strategi bisnisnya dengan baik. Dengan kata lain, penerapan TI bertujuan untuk seoptimal mungkin mengantarkan organisasi mencapai visi dan misinya (Afrianto, 2009). Berdasarkan diskusi yang dilakukan peneliti dengan Manager Departemen Management Information System (MIS) diketahui bahwa diperlukan adanya sebuah audit pada SI ERP yang diimplementasikan di PT BRL.

Menurut Akkermans et al. (2003), ERP adalah sebuah sistem yang berkontribusi terhadap standarisasi, globalisasi dan transparansi terhadap proses bisnis. Menurut Lee et al. (2010), ERP dianggap menjadi kunci untuk memperoleh keunggulan kompetitif dalam cepatnya perubahan lingkungan bisnis global. ERP juga merupakan konsep pemikiran secara terpadu, terstandar dan otomatis dalam sebuah Sistem. Ketika sebuah Sistem ERP yang dipilih lalu diperkenalkan untuk kemudian diterapkan maka organisasi akan mendapat banyak manfaat seperti mengurangi biaya yang dikeluarkan oleh organisasi, meningkatkan respon terhadap pelanggan serta meningkatkan kinerja organisasi secara keseluruhan. Pemanfaatan sistem merujuk pada penggunaan teknologi informasi oleh pengguna melalui sistem informasi berbasis komputer dalam rangka menyelesaikan tugas dan masalah yang dihadapi oleh pengguna dalam menjalankan pekerjaannya untuk meningkatkan kualitas dan produkstifitas baik secara individual, kelompok maupun organisasi dengan menfokuskan pada level individu, khusunya pada end user computing (Widuri, 2010).

Berawal dari kondisi tersebut, penelitian ini berusaha melakukan audit pada domain perencanaan dan implementasi SI PT BRL melalui penentuan Critical Success Factor (CSF), Key Gol Indicator (KGI), Key Performance Indicator (KPI), mengukur maturity level serta merekomendasikan temuan serta peluang kepada pihak manajemen dalam rangka evaluasi dan peningkatan tingkat kematangan SI PT BRL menggunakan kerangka kerja Control Objective for Information and related Technology (COBIT). Alasan menggunakan COBIT sebagai kerangka kerja dalam penelitian ini mempertimbangkan perbandingan penelitian Silitonga dan Ali (2010) dalam tesisnya 
yang berjudul Sistem Manajemen Insiden dengan menggunakan kerangka kerja Information Technology Infrastructure Library (ITIL) dibandingkan penelitian Fitrianah dan Sucahyo (2010) yang melakukan benchmarking antara kerangka kerja (framework) Audit SI yang ada di Queensland Audit Office dan kemudian semua kerangka Audit SI tersebut dipetakan dan disimpulkan bahwa COBIT adalah kerangka kerja audit SI yang paling lengkap.

Ruang lingkup penelitian ini adalah menganalisis pada proses Perencanaan (Planning and Organisation - PO) dan Implementasi (Acquisition and Implementations - AI) Sistem Informasi ERP dalam hal ini Sistem SAP pada PT BRL dengan menentukan CSF, KGI, KPI dan melakukan pengukuran maturity level menggunakan maturity model yang ada di kerangka kerja COBIT melalui studi pustaka, observasi, wawancara dan penyebaran kuesioner untuk mendapatkan data. Pemilihan kedua domain tersebut disesuaikan dengan permasalahan dan kebutuhan PT BRL dalam melakukan pengelolaan TI, mencakup strategi dan taktik, serta perhatian pada identifikasi cara TI, realisasi, implementasi dan integrasi strategi TI dalam memberikan kontribusi terbaiknya pada pencapaian proses bisnis. Beberapa cara yang umum dilakukan dalam melaksanakan penilaian maturity diantaranya adalah (Guldentops, 2003): Pendekatan multidisiplin kelompok orang yang mendiskusikan dan menghasilkan kesepakatan level maturity kondisi sekarang; Dekomposisi deskripsi maturity menjadi beberapa pernyataan sehingga manajemen dapat memberikan tingkat persetujuannya; dan Penggunaan atribut matriks sebagaimana didokumentasikan dalam COBIT's management guidelines dan memberikan nilai masing-masing atribut dari setiap proses. Keberhasilan dari proyek implementasi SI ditentukan dari perspektif keberhasilan investasi sistem, keberhasilan pelaksanaan proyek dan kesesuaian SI sesuai fungsi yang diinginkan (Hallikainen dan Chen, 2005).

\section{METODE PENELITIAN}

Penelitian ini dilakukan di kantor PT BRL selama lima bulan, menggunakan dua jenis data yaitu data primer dan data sekunder. Data primer diperoleh dari observasi, wawancara serta pengisian kuesioner yang dilakukan oleh responden internal atau karyawan PT BRL yang merupakan populasi user dari SI, SAP terdiri dari tiga puluh orang dari level staf hingga manajerial yang merupakan representative dari manajemen. Data sekunder diperoleh dari data dan informasi yang terkait dengan bidang penelitian ini baik dari dokumen internal perusahaan, media cetak, website, jurnal, tesis, disertasi dan studi pustaka.

Data yang terkumpul dari dianalisis menggunakan panduan yang ada dalam melakukan sebuah analisa IT assurance guide dan maturity model dengan skala likert meliputi detailed control objective yang disesuaikan dengan keadaan dari PT BRL (berdasar pada high level control objective), dimana model ini dapat mengukur maturity level dari level pengembangan manajemen proses. Seberapa bagusnya pengembangan dan implementasiatau kapabilitas Manajemen tergantung pada tercapainya tujuan-tujuan COBIT. Menurut IT Governance Institute, tingkat kemampuan pengelolaan TI pada skala maturity dibagi menjadi enam tingkatan, mulai dari level 0 (non-existent), level 1 (initial), level 2 (repeatable), level 3 (defined), level 4 (managed) dan level 5 (optimized). Model yang digunakan untuk mengaudit berbentuk kuesioner yang berasal dari COBIT maturity model serta bergantung pada konsep skenario, di mana setiap maturity level dianggap sebagai skenario. Pederiva (2003) mengemukakan bahwa skenario maturity level mencakup deskripsi dari organisasi dan kontrol internal perusahaan yang memenuhi persyaratan maturity level tertentu. Setelah proses analisis dari hasil audit SI selesai. Selanjutnya, adalah proses dokumentasi temuan-temuan hasil Audit SI dan membuat suatu kesimpulan serta rekomendasi dan solusi terhadap hasil Audit SI.

Langkah pengumpulan data dan informasidalam penelitian ini dilaksanakan melalui: Melakukan Informal Brainstorming Group Session secara langsung pada responden yang bertujuan menentukan setiap proses dan control objective dari proses perencanaan dan implementasi SI, serta menentukan CSF, KGI dan KPI. Membuat dan menggunakan kuesioner yang dikembangkan berdasarkan model kematangan COBIT 4.1 dan dikaitkan dengan control objective serta atribut kematangan yang memengaruhi untuk disebarkan pada responden. Melakukan wawancara yang dilakukan secara langsung ke responden. Melakukan observasi yang dilakukan secara langsung pada objek penelitian dengan mengadakan pengamatan dan pengumpulan data serta informasi yang diperlukan terkait dengan proses Perencanaan dan Implementasi SI PT BRL. Melakukan studi pustaka dengan membaca, mempelajari dan mengutip berbagai karya ilmiah seperti buku, tesis, 
disertasi, jurnal dan dokumen internal maupun dokumen eksternal yang berkaitan dengan penelitian ini. Hasil pengisian kuesioner, wawancara dan observasi tersebut menghasilkan nilai pencapaian terhadap standar dan dapat dihitung untuk masing-masing maturity level melalui pengumpulan seluruh jawaban dari responden untuk dijumlahkan nilai pencapaian setiap pernyataan. Penilai menggunakan Indeks hasil yang diperoleh dari nilai $\sum$ (Jawaban) dibagi dengan $\sum$ (Soal).

Audit SI di penelitian ini menerapkan metodologi audit SI yang sesuai dengan metodologi yang diajukan oleh IT Assurance Guide: Using COBIT. Namun, dengan alasan untuk tidak mengurangi pengulangan aktivitas tidak semua langkah yang ada di dalam panduan tersebut dilaksanakan semuanya. Alur kerangka pemikiran penelitian ini dapat dilihat pada Gambar 1 .

Tahapan yang ditempuh dalam pelaksanaan audit SI ini adalah sebagai berikut: (1) Menentukan ruang lingkup dan tujuan dari audit SI, (2)Membuat kerangka Audit SI, (3) Menentukan control objectives, CSF, KGI, KPI sesuai ruang lingkup dalam penelitian ini. (4) Melakukan audit SI sesuai kerangka kerja COBIT melalui pengumpulan data dan informasidari responden melalui kuesioner, wawancara dan observasi langsung. Pembuatan kuesioner menggunakan deskripsi dari maturity level yang ada di COBIT maturity model dan tujuan dari kuesioner ini dibuat adalah untuk mendapatkan informasi terkait dengan kondisi perusahaan dengan berbagai skenario yang menggambarkan dalam setiap maturity level. Deskripsi kuesioner tingkat maturity level adalah pernyataan yang bernilai sangat tidak baik, tidak baik, cukup baik, baik atau sangat baik dan dapat dilihat sebagai sebuah pernyataan yang berdiri sendiri. (5) Penyusunan kuesioner berdasarkan kombinasi literatur dan jurnal dengan prosedur System Development Life Cycle (SDLC) pada PT BRL. Jika proses TI SDLC relevan dengan salah satu prosedur SDLC pada PT BRL maka proses TI SDLC tersebut applicable sehingga dapat dijadikan fokus area evaluasi penerapan prosedur SDLC di PT BRL dan sebagai dasar dalam membuat pertanyaan kuesioner. Sebaliknya, jika tidak relevan maka proses TI tersebut tidak dipakai dalam evaluasi. Applicable berarti prosedur kontrol yang ada dalam suatu proses TI SDLC dapat diterapkan ke dalam aktivitas TI di beberapa tahapan SDLC. Hasil analisa dalam pemetaan proses TI SDLC dengan tahapan prosedur PT BRL dapat dilihat pada Tabel 1.

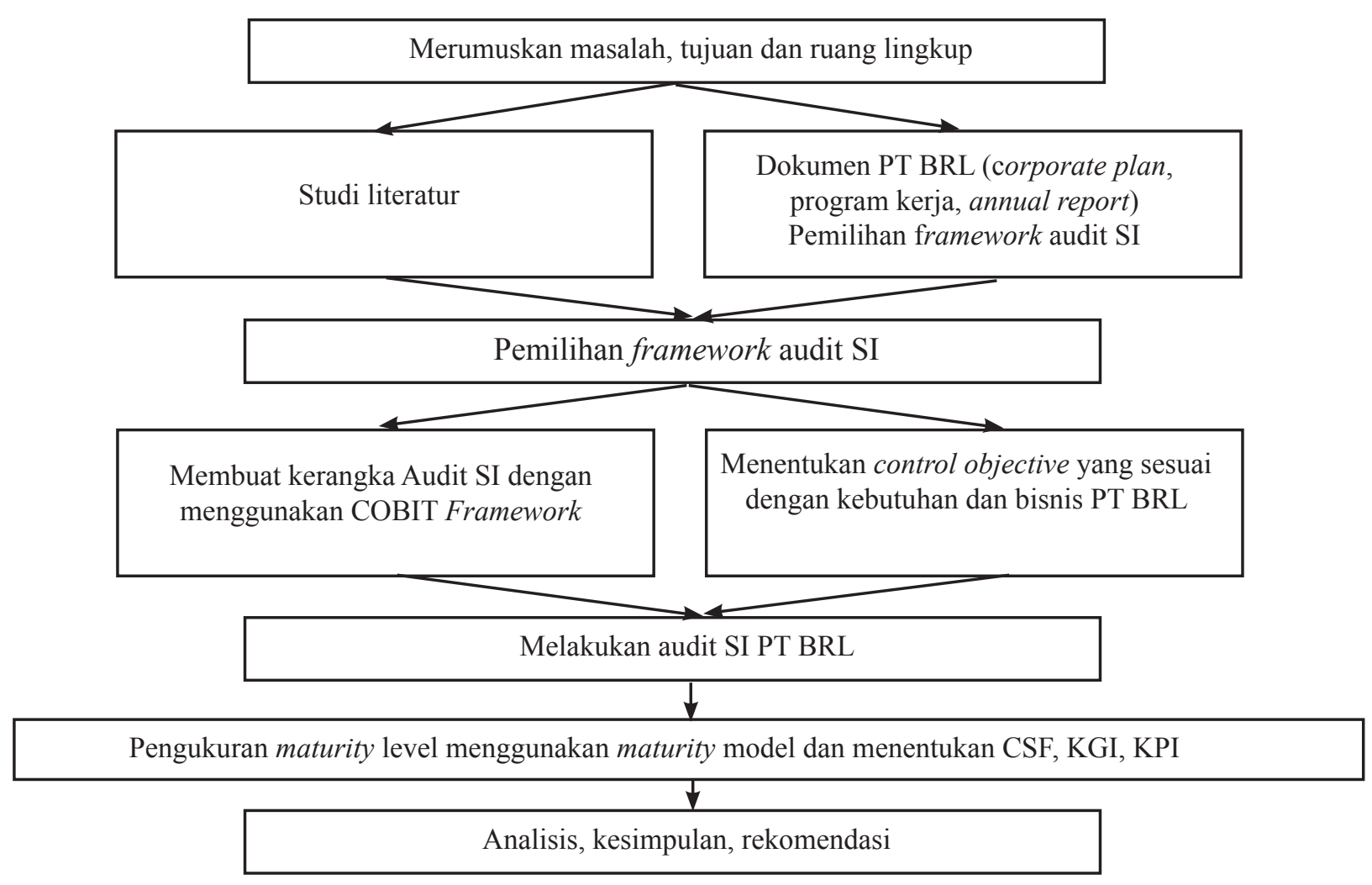

Gambar 1. Kerangka pemikiran penelitian 
Tabel 1. Pemetaan proses TI SDLC Sistem Informasi (SI) PT BRL

\begin{tabular}{lll}
\hline \multicolumn{1}{c}{ Proses TI } & \multicolumn{1}{c}{ Status } & \multicolumn{1}{c}{ SDLC PT BRL } \\
\hline PO1 (Menentukan perencanaan strategi TI) & Applicable & Project Preparation \\
PO2 (Menentukan arsitektur informasi) & Applicable & Business Blueprint \\
PO3 (Menentukan arah teknologi) & Applicable & Business Blueprint \\
PO4 (Mendefinisikan proses, organisasi dan hubungan TI) & Not Applicable & - \\
PO5 (Mengelola investasi TI) & Not Applicable & - \\
PO6 (Mengkomunikasikan tujuan dan arah manajemen) & Applicable & Business Blueprint, Realization \\
PO7 (Mengelola SDM TI) & Applicable & Project Preparation, Go Live \& Support \\
PO8 (Mengelola mutu) & Not Applicable & - \\
PO9 (Menjamin dan mengelola risiko-risiko TI) & Applicable & Business Blueprint, Realization \\
PO10 (Mengelola proyek) & Not Applicable & - \\
AI1 (Identifikasi solusi yang otomatis) & Not Applicable & - \\
AI2 (Memperoleh dan memelihara aplikasi perangkat lunak) & Applicable & Realization \\
AI3 (Memperoleh dan memelihara infrastruktur teknologi) & Applicable & Realization, Final Preparation \\
AI4 (Memungkinkan operasi dan penggunaannya) & Not Applicable & - \\
AI5 (Memperoleh sumberdaya TI) & Not Applicable & - \\
AI6 (Mengatur perubahan) & Applicable & Final Preparation, Go Live \& Support \\
AI7 (Memasang serta mengakreditasi solusi dan perubahan) & Applicable & Final Preparation, Go Live \& Support \\
\hline
\end{tabular}

\section{HASIL}

\section{Audit Domain Perencanaan dan Implementasi Sistem Informasi (SI) PT BRL}

Pada peta strategi perusahaan setiap penyebab dari masing-masing perspektif harus memiliki hubungan sebab akibat (cause and effect linkage) antara satu dengan yang lainnya (Arofah, 2012). Sesuai dengan ruang lingkup penelitian maka audit SI PT BRL dilakukan terhadap proses Perencanaan dan Implementasi. Penentuan control objective ditentukan bedasarkan hasil dari Informal Brainstorming Group Session dan kebutuhan dari proses bisnis SI PT BRL. Domain dan control objectives SI PT BRL terdapat pada Tabel 2.

Sesuai dengan rumusan masalah, tujuan dan ruang lingkup penelitian ini maka CSF, KGI dan KPI pada proses Perencanaan dan Implementasi SI di PT BRL adalah sebagai berikut: pada proses perencanan membahas mengenai strategi, taktik, dan identifikasi dari SI yang bertujuan mendukung pencapaian tujuan dari bisnis. Realisasi dari visi dan strategi SI perlu direncanakan, dikomunikasikan dan diatur serta dilihat dari berbagai macam perspektif, seperti dari segi organisasi, segi infrastruktur teknologi dan sebagainya yang dapat dilihat lebih rinci sebagai berikut :

\section{a) Menentukan Perencanaan Strategi TI (PO1)}

CSF: Melakukan dokumentasi dari perencanaan strategi TI, rencana strategi TI mempertimbangkan resiko yang akan timbul, rencana strategi TI telah dipetakan sesuai dengan kebutuhan PT BRL; KGI: Manajemen mengerti dan memahami tujuan dari strategi SI yang terkait dengan tujuan PT BRL, perencanaan TI mencakup sebagian besar divisi dan user di PT BRL, dialokasikannya anggaran terhadap TI oleh manajemen; KPI: Perencanaan TI dibagi menjadi perencanaan strategi TI dan perencanaan operasional TI; User ikut serta dalam perencanaan strategi TI.

b) Menentukan Arsitektur Informasi (PO2)

CSF: Data ownership dialokasikan dan disetujui; fungsi data administrator SI telah ditetapkan dengan mengikuti standar, menjaga komponen infrastruktur SI tetap konsisten, seperti arsitektur informasi, kamus data, sintaks data dan tingkat keamanan; KGI: Pengembangan aplikasi yang lebih cepat, terpenuhinya kebutuhan data akan keamanan, ketersediaan dan integrasi SI, pengurangan pengulangan data; KPI: Terdapat dokumentasi klasifikasi data, pengurangan insiden yang disebabkan karena model data tidak konsisten. 
Tabel 2. Domain dan Control objectives Sistem Informasi (SI) PT BRL

\begin{tabular}{cl}
\hline \multicolumn{1}{c}{ Domain } & \multicolumn{1}{c}{ Control Objectives } \\
\hline Perencanaan & $\begin{array}{l}\text { 1. PO1: Menentukan perencanaan } \\
\text { strategi TI }\end{array}$ \\
& $\begin{array}{c}\text { 2. PO2: Menentukan arsitektur informasi } \\
\text { 3. PO3: Menentukan arah teknologi } \\
\text { 4. PO6: Mengkomunikasikan tujuan dan } \\
\text { arah Manajemen }\end{array}$ \\
& 5. PO7: Mengelola SDM TI \\
& 6. PO9: Menjamin dan mengelola risiko- \\
& risiko TI \\
Implementasi & 1. AI2: Memperoleh dan memelihara \\
& aplikasi perangkat lunak \\
2. AI3: Memperoleh dan memelihara & teknologi infrastruktur \\
& 3. AI6: Mengatur perubahan \\
4. AI7: Memasang dan mengakreditasi \\
dan perubahan
\end{tabular}

c) Menentukan Arah Teknologi (PO3)

CSF: Perubahan teknologi dimonitor secara rutin untuk mengamati ancaman dan kesempatan, perencanaan infrastruktur teknologi meliputi rencana akuisi SI dan pelatihan berdasarkan standar tertentu, adanya strategi terhadap infrastruktur teknologi untuk perubahan dari Sistem yang dulu menuju Sistem yang baru; KGI: Semakin meningkatnya jumlah teknologi dan platform yang kompatibel, jumlah teknologi platform yang harus dipelihara berkurang, berkurangnya waktu dan usaha untuk memberikan perawatan pada user; KPI: Teknologi digunakan untuk mendukung kegiatan PT BRL, dilakukan proses identifikasi teknologi baru yang potensial dan keputusan apa yang akan dilakukan dengan teknologi tersebut.

d) Mengkomunikasikan Arah dan Tujuan Manajemen (PO6)

CSF: Manajemen memimpin dan memberikan contoh, terdapat pedoman yang praktis mengenai kebijakan dan prosedur, kebijakan kontrol informasi current dan up to date; KGI: Meningkatnya jumlah Divisi yang mengerti kebijakan dan prosedur SI, jumlah prosedur dan kebijakan yang cukup mengenai kontrol TI; KPI: Diterapkannya kebijakan pada prosedur operasional, Manajemen mengkomunikasikan kebijakan dan prosedur secara reguler.

\section{e) Mengelola SDM TI (PO7)}

CSF: SDM TI terlibat dalam pengambilan keputusan, mendukung fungsibisnis, mempunyai peranan serta kewajiban yang jelas dan berkualitas; KGI: Berkurangnya jumlah proyek yang terlambat karena kelalaian atau ketidakmampuan dari SDM TI, sebagian besar Divisi di PT BRL telah didukung oleh SDM TI, dilakukan survey penilaian SDM TI terhadap kinerja, moral dan kepuasan user; KPI: Fungsi SDM TI ditujukan untuk mendukung struktur organisasi PT BRL, fungsiyang penting diidentifikasikan secara ekspilisit pada struktur organisasi Sistem Informasi (SI) dan SDM dengan peranan dan tanggung jawab yang jelas.

\section{f) Menjamin dan Mengelola Risiko-risiko TI (PO9)}

CSF: Terdapat kebijakan untuk mendefinisikan batasan risiko dan toleran SI, fokus penilaian terutama pada keadaan real dan bukan pada teorinya, dilakukan analisis indentifikasi risiko dan penanggulangannya; KGI: Meningkatkan kepedulian pada kebutuhan penilaian risiko, peningkatan jumlah risiko yang teridentifikasi, peningkatan jumlah proses SI yang penilaian risikonya sudah di dokumentasikan secara formal; KPI: dilakukan pemonitoran terhadap laporan risiko, terdapat pelatihan untuk memahami metodologi manajemen risiko.

g) Memperoleh dan Memelihara Aplikasi Perangkat Lunak (AI2)

CSF: Manajemen mendukung menyetujui dan mengerti metodologi terhadap akuisisi SI dan implementasi perangkat lunak, praktek akuisisi SI perangkat lunak dimengerti secara jelas dan diterima, adanya pemisahan antara aktivitas pengembangan dan pengujian perangkat lunak aplikasi, dilakukan pendekatan dan usaha dalam menghubungkan bisnis dengan aplikasi; KGI: Meningkatkanya jumlah aplikasi yang selesai tepat waktu, memenuhi spesifikasi, dan sejajar dengan arsitektur teknologi SI, meningkatnya jumlah aplikasi tanpa masalah integrasi selama implementasi, berkurangnya biaya pemeliharaan setiap aplikasi; KPI: Berkurangnya insiden yang disebabkan ketidaksesuaian terhadap standar, seperti aplikasi yang tidak terdokumentasi, desain yang tidak disetujui dan pengujian yang tidak memenuhi batas waktu, didokumentasikannya pemeliharaan terhadap perangkat lunak aplikasi secara efektif. 
h) Memperoleh dan Memelihara Infrastruktur Teknologi (AI3)

CSF: Praktik akuisisi teknologi infrastruktur jelas, dimengerti dan diterima, adanya integrasi SI antara platform teknologi yang berbeda, adanya metodologi Siklus hidup yang digunakan untuk memilih, mendapatkan, menjaga dan mengganti teknologi infrastruktur; KGI: Berkurangnya jumlah platform yang menyimpang dari persetujuan teknologi infrastruktur, berkurangnya jumlah masalah dalam implementasi Sistem yang disebabkan oleh infrastruktur yang tidak memadai, berkurangnya perawatan dan pengembangan infrastruktur baru; KPI: Terintegrasinya platform yang berbeda-beda, dilakukan perawatan yang bersifat preventif.

\section{i) Mengatur Perubahan (AI6)}

CSF: Dilakukan proses identifikasi dan penentuan prioritas terhadap perubahan, dilakukan pengujian menyeluruh terhadap kelayakan sebelum melakukan perubahan, terdapat proses formal serah terima dari tahap pengembangan ke operasional, terdapat dokumentasi dan konfigurasi yang lengkap dan up to date, terdapat proses verifikasi kesuksesan/kegagalan terhadap perubahan; KGI: Berkurangnya jumlah gangguan yang disebabkan perubahan yang kurang diatur dengan baik, berkurangnya tingkat sumber daya dan waktu yang dibutuhkan terhadap perubahan, berkurangnya jumlah perbaikan yang bersifat urgent; KPI: Berkurangnya jumlah perbaikan yang bersifat gawat dan disebabkan proses pengaturan perubahan tidak diterapkan secara regular, dilakukan review terhadap permintaan perubahan implementasi.

\section{j) Memasang serta Mengakreditasi Solusi dan Perubahan (AI7)}

CSF: Dilakukan pengujian yang cukup terhadap sistem yang baru, diimplementasikan mekanisme feedback untuk melakukan optimasi dan peningkatan proses secara terus menerus, adanya komitmen keikutsertaan manajemen dalam pelatihan dan proses transisi; KGI: Berkurangnya jumlah Sistem operasi yang tidak terakreditasi, berkurangnya jumlah perubahan setelah pengujian terhadap penerimaan suatu sistem; KPI: Proses instalasi dan akreditasi yang terutama SI, meningkatnya kepuasan user terhadap proses instalasi dan akreditasi.

\section{Maturity Level PT BRL}

Hasil pengukuran maturity level untuk proses perencanaan danimplementasiSIPTBRLmenggunakan COBIT Maturity Model dapat dilihat pada Tabel 3. Maturity level untuk PO2, PO3, PO6, PO7, PO9, AI2, AI3 dan AI7 berada pada level 3(defined). Sudah ada prosedur yang memiliki standar dan didokumentasikan dengan baik, sudah ada pelatihan formal untuk mengkomunikasikan prosedur dan kebijakan yang dibuat. Namun pada tahap implementasinya masih tergantung pada individu apakah mau melakukan prosedur yang ditetapkan atau tidak. Prosedur yang dibuat masih terbatas pada bentuk formalisasi dari praktik yang ada.

Control Objectives untuk PO1 dan AI6 berada pada level 2 (repeatable). Prosedur yang sama telah dikembangkan dalam proses-proses untuk menangani suatu tugas, dan diikuti oleh setiap orang yang terlibat didalamnya. Aktivitas yang serupa sudah dilakukan oleh orang-orang yang berbeda tetapi tidak ada pelatihan formal atau komunikasi standar prosedur. Tanggung jawab diserahkan kepada setiap individu. Kepercayaan terhadap pengetahuan individu sangat tinggi sehingga seringkali terjadi kesalahan. Secara keseluruhan ratarata skor yang didapatkan dari $\mathrm{P} 01, \mathrm{PO} 2, \mathrm{PO} 3, \mathrm{PO}$, PO7, PO9, AI2, AI3, AI6 dan AI7 adalah 2,99 dapat dibulatkan menjadi 3 , yang berarti ini berada pada level defined.

\section{Rekomendasikan Temuan Serta Peluang Kepada Pihak PT BRL}

Belum ditemukan adanya komitmen dari manajemen secara langsung dan formal untuk perencanaan dan implementasi pengembangan sistem. SI SAP belum direncanakan untuk dapat mengakomodasi semua kebutuhan informasidi lingkungan PT BRL. Tidak semua user di lingkungan internal PT BRL dilibatkan pada saat perencanaan dan implementasi pengembangan SI SAP Secara keseluruhan, prosedur SI di PT BRL yang berhubungan dengan perencanaan dan implementasi pengembangan SI SAP sudah didokumentasikan, distandarisasi dan dirawat dengan baik, namun pelaksanaan dan evaluasi belum dilakukan secara regular dan konsisten. Pada tahap perencanaan dan implementasi pengembangan SI, kebijakan dan prosedur yang berkaitan pada pengelolaan, perubahan database, keamanan, penanganan, penyimpanan dan back-up database SI SAP sudah diatur didalam 
dan diletakkan didalam sistem dan prosedur. Proses pengawasan pada perubahan yang dilakukan sudah memadai serta telah ditetapkan secara formal namun belum dijalankan secara reguler dan konsisten. Pada tahap perencanaan dan implementasi pengembangan SI belum membahas secara formal tentang kualitas data dari SI, belum ditetapkan penggunaan manajemen kunci kriptografi (enskripsi) untuk password, user id dan aliran data serta belum dibahas tentang pemeriksaan akurasi, validasi, kelengkapan dan otorisasi database SI yang dilakukan secara berkala dan periodik. Pada tahap perencanaan dan implementasi SI, belum diatur suatu prosedur baku untuk SI di PT BRL.Implikasi manajerial sebagai masukan yang diusulkan dari hasil penelitian ini adalah meningkatkan maturity level menjadi level 4 (Managed). Artinya, sudah memungkinkan untuk memantau dan mengukur ketaatan pada prosedur sehingga dapat dengan mudah ditanggulangi apabila terjadi penyimpangan pada aktivitas. Perbaikan proses dilakukan secara konstan. Implementasi proses dilakukan secara baik. Otomasi dan perangkat yang digunakan terdapat pada Tabel 4.

Hasil penelitian dapat diketahui bahwa penelitian ini sesuai dengan hasil penelitian Purnomo (2010) yang berjudul Perancangan Model Tata Kelola Ketersediaan Layanan TI Menggunakan Framework COBIT pada Badan Pemeriksa Keuangan Republik Indonesia (BPK-RI) dan penelitian Suhardi (2011) yang berjudul Evaluasi Kematangan Pengelolaan TI pada PT Multi Garmenjaya Surabaya dengan menggunakan pendekatan COBIT. Terdapat kesenjangan yang diperbaiki dengan rekomendasi untuk meningkatkan kematangan sesuai yang diharapkan.
Selain rekomendasi, penelitian dilengkapi dengan outcome measure dan performance indicator serta draft kebijakan yang dapat menjadi panduan dalam mengelola ketersediaan layanan TI berdasarkan COBIT framework. Serupa dengan penelitian Purwanto (2010) berjudul Evaluasi Kelola TI menggunakan COBIT framework dalam mendukung layanan SI Akademik di Universitas Budi Luhur dimana ditemukan masih kurangnya komunikasi atau pelatihan formal terhadap prosedur standar dan tanggung jawab masih diserahkan kepada individu. Selain itu masih terdapat kepercayaan yang tinggi terhadap kemampuan individu, sehingga kesalahan sangat mungkin terjadi.

Seperti hasil penelitian Dermawan R (2012) dengan judul Model Tata Kelola Pengelolaan Jaringan di PT X Menggunakan COBIT dan penelitian Budiawan (2012) dengan judul Evaluasi Kematangan Pengelolaan Infrastruktur Teknologi Informasi Menggunakan COBIT di BPK-RI, organisasi mengharapkan mencapai tingkat kematangan SI yang lebih baik dengan adanya peningkatan standar pengelolaan jaringan baik Sistem aplikasi, infrastruktur, proses bisnis dan solusi teknologi serta monitoring dalam praktiknya. Dalam mencapai tingkat yang diinginkan pada umumnya penulis dan organisasi menyusun strategi perubahan sesuai tingkat perubahan yang direncanakan. Rencana perbaikan dibuat untuk mencapai kondisi yang diharapkan, yaitu merumuskan cara serta target waktu pencapaian dengan mempertimbangkan kondisi sumber daya yang ada dan manajemen dapat memadukan hasil penelitian dengan menggunakan tools yang lain, misalnya ITIL sehingga pada pelaksanaanya dapat lebih terintegrasi dan lebih teknis.

Tabel 3. Hasil pengukuran maturity level pada proses perencanaan dan implemetasi

\begin{tabular}{lccc}
\hline \multicolumn{1}{c}{ Proses } & Indeks & Pembulatan & Level \\
\hline Menentukan perencanaan strategi (P01) & 2,48 & 2 & Repeatable \\
Menentukan arsitektur informasi(P02) & 3,22 & 3 & Defined \\
Menentukan arahan teknologi (P03) & 3,16 & 3 & Defined \\
Mengkomunikasikan tujuan dan arah manajemen (P06) & 3,15 & 3 & Defined \\
Mengelola SDM TI (P07) & 3,00 & 3 & Defined \\
Menjamin dan mengelola risiko-risiko TI (P09) & 3,01 & 3 & Defined \\
Memperoleh dan memelihara aplikasi perangkat lunak (AI2) & 3,10 & 3 & Defined \\
Memperoleh dan memeliharan infrastruktur teknologi(AI3) & 3,32 & 3 & Defined \\
Mengatur perubahan (AI6) & 2,46 & 2 & Repeatable \\
Memasang dan mengakreditasi solusi dan perubahan (AI7) & 3,05 & 3 & Defined \\
\hline
\end{tabular}


Tabel 4. Rekomendasi dari hasil audit proses perencanaan dan implementasi

\begin{tabular}{|c|c|}
\hline Domain/proses & Rekomendasi \\
\hline $\begin{array}{l}\text { Menentukan } \\
\text { perencanaan strategi } \\
\text { TI. }\end{array}$ & $\begin{array}{l}\text { 1. Manajemen harus melakukan pemantauan terhadap IT strategic plan secara periodik } \\
\text { 2. Manajemen dan seluruh user terlibat aktif di proses perencanaan } \\
\text { 3. Dokumentasi terhadap proses perencanaan dilakukan secara periodik }\end{array}$ \\
\hline $\begin{array}{l}\text { Menentukan arsitektur } \\
\text { informasi }\end{array}$ & $\begin{array}{l}\text { 1. Klasifikasi data didokumentasikan secara periodik } \\
\text { 2. Adanya kebijakan terhadap kamus data yang bertujuan menjaga konsistensi data }\end{array}$ \\
\hline $\begin{array}{l}\text { Menentukan arahan } \\
\text { teknologi }\end{array}$ & $\begin{array}{l}\text { 1. Proses perencanaan teknologi harus mempertimbangkan trend teknologi } \\
\text { 2. Manajemen perlu memperhatikan dampak implementasi teknologi terhadap lingkungan internal } \\
\text { 3. Perlu dilakukan peningkatan teknologi secara periodik untuk meningkatkan tingkat efektivitas } \\
\text { aktivitas perusahaan }\end{array}$ \\
\hline $\begin{array}{l}\text { Mengkomunikasikan } \\
\text { tujuan dan arah } \\
\text { manajemen }\end{array}$ & $\begin{array}{l}\text { 1. Pengendalian keamanan harus diawasi dan diperbaharui secara periodik } \\
\text { 2. Manajemen dituntut aktif untuk menghimbau dan melakukan sosialisasi dalam menjaga } \\
\text { lingkungan TI }\end{array}$ \\
\hline Mengelola SDM TI & $\begin{array}{l}\text { 1. Diperlukan evaluasi mengenai pelaksanaan dan tanggung jawab setiap personil di Divisi TI } \\
\text { 2. Pelatihan mengenai teknik dan prosedur keamanan informasibagi karyawan di Divisi TI harus } \\
\text { dilakukan secara formal dan terjadwal }\end{array}$ \\
\hline $\begin{array}{l}\text { Menjamin dan } \\
\text { mengelola risiko- } \\
\text { risiko TI }\end{array}$ & $\begin{array}{l}\text { 1. Harus dilakukan analisa dan identifikasi risiko, mitigasi risiko serta tata cara } \\
\text { penanggulangannya } \\
\text { 2. Identifikasi risiko harus dimasukkan ke dalam perencanaan TI }\end{array}$ \\
\hline $\begin{array}{l}\text { Mendapatkan dan } \\
\text { memelihara aplikasi } \\
\text { software }\end{array}$ & $\begin{array}{l}\text { 1. Ditetapkan metodologi terhadap siklus pengembangan sistem secara konsisten } \\
\text { 2. Dilakukan pemisahan antara aktivitas pengembangan dan pengujian software aplikasi } \\
\text { 3. Dokumentasi terhadap implementasisoftware aplikasi dilakukan secara konsisten dan periodik }\end{array}$ \\
\hline $\begin{array}{l}\text { Memperoleh dan } \\
\text { memelihara teknologi } \\
\text { infrastruktur }\end{array}$ & $\begin{array}{l}\text { 1. Setiap akuisisi infrastruktur teknologi harus mempertimbangkan trend teknologi dan kebutuhan } \\
\text { keamanan } \\
\text { 2. Harus dilakukan pemantauan terhadap seluruh infrastruktur yang dimiliki }\end{array}$ \\
\hline Mengatur perubahan & Perencanaan dan manajemen perubahan perlu dipantau serta diperbahurui secara regular \\
\hline $\begin{array}{l}\text { Memasang, } \\
\text { mengakreditasi solusi } \\
\text { dan perubahan. }\end{array}$ & $\begin{array}{l}\text { 1. Diperlukan prosedur formal terhadap akreditasi dan instalasi sistem } \\
\text { 2. Harus ada standarisasi terhadap kriteria kesuksesan pengujian sistem } \\
\text { 3. Manajemen terlibat dalam menentukan kualitas setiap sistem yang diimplementasikan }\end{array}$ \\
\hline
\end{tabular}

Hasil analisis tingkat kematangan tata kelola SI pada PT BRL saat ini, maka dapat diketahui bahwa tingkat kematangan tersebut diidentifikasikan berada pada level 2 dan 3. Belum ditemukan acuan tingkat kematangan Sistem secara pasti dalam industri jasa pelayaran lepas pantai penunjang operasi migas yang digeluti PT BRL. Berdasarkan observasi dan wawancara dengan beberapa pelanggan pada industri jasa pelayaran lepas pantai jasa penunjang operasi migas, sebagai perusahaan jasa PT BRL menilai kematangan dan kehandalan SI menjadi modal utama bagi perusahaan dalam menjalankan operasi, menjamin keselamatan kerja dan memberikan jasa layanan. Dapat disimpulkan bahwa standar minimum tingkat maturity level SI industri jasa pelayaran lepas pantai penunjang operasi migas adalah pada level 4. Dapat dibandingkan bahwa secara umum PT BRL belum memenuhi standar industri seperti yang diinginkan oleh pelanggannya karena maturity level SI PT BRL masih berada pada level 2 dan 3.

Selain mengukur dan menganalisa tingkat kematangan SI pada BRL, penelitian ini juga mengkonfirmasi apakah manajemen PT BRL telah merasa cukup dengan kondisi SI yang existing sekarang ataukah masih mengharapkan peningkatan yang akan ditindaklanjuti dengan perumusan rencana-rencana strategis SI untuk meningkatkan tingkat kematangan SI pada PT BRL. Berdasarkan diskusi dan wawancara dengan pihak manajemen dan manajer Departemen Management Information System (MIS) diketahui bahwa manajemen menginginkan adanya peningkatan untuk dapat bersaing dengan organisasi lain di industri jasa yang sejenis untuk meningkatkan maturity level setiap domain yang saat ini masih pada level 2 dan 3 menjadi lebih baik, yaitu di level 4 (managed and measurable).

Proses perbaikan tata kelola teknologi informasidi PT BRL untuk meningkatkan dan memperbaiki kondisi saat ini dilakukan dengan strategi sebagai berikut:

1) Langkah perbaikan dilakukan secara bertahap untuk mencapai tingkat kematangan level 4 (managed and measurable) (Gambar 2).

2) Proses dengan tingkat kematangan saat ini berada pada level 2 (repeatable but intuitive) mendapat prioritas utama untuk dilakukan perbaikan sehingga tercapai keseimbangan tingkat kematangan untuk 
semua proses, semua proses memiliki tingkat kematangan yang sama, yaitu pada level 3 (defined process).

3) Setelah tercapai kondisi keseimbangan tingkat kematangan saat ini untuk semua proses, maka dilakukan langkah perbaikan tata kelola SI untuk semua proses secara bersama-sama menuju tingkat kematangan level 4 (managed and measurable) (Gambar 2).

\section{Implikasi Manajerial}

Control Objective for Information and related Technology (COBIT) framework bersifat umum, penentuan domain dan control objectives perlu dilakukan penyesuaian lebih dahulu dengan kebutuhan proses bisnis SI dan tanggung jawab dari proses SI terhadap aktivitas organisasi yang sesuai dengan ruang lingkup dalam penelitian ini, proses audit SI yang dilakukan hanya pada sistem SAP, diharapkan untuk penelitian selanjutnya yang dilakukan di PT BRL audit SI dilakukan pada SI lainnya yang ada, seperti sistem Human Resources Information System dan Payroll. Penelitian ini hanya melakukan audit SI pada dua domain yang ada pada COBIT framework, yaitu perencanaan (planning and organisation) dan Implementasi (acquisition and implementations).

\section{KESIMPULAN DAN SARAN}

\section{Kesimpulan}

Hasil penelitian dan pembahasan analisis tata kelola SI pada PT BRL dapat disimpulkan bahwa tata kelola SI pada PT BRL saat ini secara umum telah cukup baik. Hal ini ditunjukkan dengan tingkat kematangan tata kelola SI yang sebagian besar berada pada tingkat kematangan level 3 (defined) dan level 2 (repeatable but intuitive). Optimisme dan tingkat harapan manajemen terhadap peningkatan tata kelola SI PT BRL cukup baik, ditunjukkan dengan keinginan pencapaian tingkat kematangan tata kelola SI pada level 4 (managed and measurable). Agar proses peningkatan tata kelola SI menuju tingkat kematangan yang diharapkan dapat optimal maka diperlukan strategi yakni perbaikan tata kelola SI yang dilakukan secara bertahap. COBIT framework dapat diadopsi untuk melakukan audit proses perencanaan dan implementasi SI di PT BRL.

\section{Saran}

Diharapkan pada penelitian selanjutnya audit SI dapat dilengkapi dengan dua domain lain yang ada di COBIT framework, yaitu Delivery and Support (DS) dan Monitoring Evaluation (ME).

\begin{tabular}{|l|l|l|l|l|l|l|l|l|l|l|}
\hline 5 & $\uparrow$ & $\uparrow$ & & $\uparrow$ & $\uparrow$ & $\uparrow$ & $\uparrow$ & $\uparrow$ & $\uparrow$ & $\uparrow$ \\
\hline 4 & & $\uparrow$ & $\uparrow$ & $\uparrow$ & $\uparrow$ & $\uparrow$ & $\uparrow$ & $\uparrow$ & & $\uparrow$ \\
\hline 3 & & & & & & & & & & \\
\hline 2 & & & & & & & & & & \\
\hline 1 & & & & & & & & & & \\
\hline 0 & & & & & & & & & & \\
\hline & PO1 & PO2 & PO3 & PO6 & PO7 & PO9 & AI2 & AI3 & AI6 & AI7 \\
\hline
\end{tabular}

Gambar 2. Strategi pencapaian tingkat kematangan yang diharapkan 


\section{DAFTAR PUSTAKA}

Adityawarman. 2012. Pengukuran tingkat kematangan penyelarasan strategi teknologi informasi terhadap strategi bisnis analisis menggunakan framework COBIT 4.1. Jurnal Akuntansi \& Auditing 8(2): 97-189.

Afrianto I. 2009. Usulan peta strategi teknologi informasi menggunakan pendekatan balanced Scorecard. Jurnal Ilmiah UNIKOM 9(1): 87-97.

Ahmad A, Musa A. 2009. Exploring COBIT process for ITG in Saudi organization. The International Journal of Digital Accounting Research 9(2009): 99-126.

Akkermans HA, Bogerd P, Yucesan E dan Wassenhove LNV. 2003. The impact of ERP on supply chain management. European Journal of Operational Research 146(2): 284-301. https://doi. org/10.1016/S0377-2217(02)00550-7.

Arofah N. 2012. Penyusunan IT balanced Scorecard untuk pengukuran kinerja divisi IT di Pertamina UPMS V surabaya. Jurnal Teknik POMITS 1(2): $1-9$.

Ayat M, Masrom M, Sahibuddin S. 2011. IT governance and small medium enterprises. Journal International Software and Computer Applications 9(1): 168-173.

Borousan E, Hojabri R, Manafi M, Hooman A. 2011. Balanced Scorecard; a tool for measuring and modifying IT governance in healthcare organizations. International Journal of Innovation, Management and Technology 2(2): 1-6.

Budiawan H. 2012. Evaluasi Kematangan Pengelolaan Standarisasi Infrastruktur Teknologi Informasi Menggunakan COBIT (Studi Kasus: Badan Pemeriksaan Keuangan RI) [tesis]. Surabaya: Institut Teknologi Surabaya.

Dermawan R. 2012. Model Tata Kelola Pengelolaan Jaringan di PT. X Menggunakan COBIT [tesis]. Surabaya: Institut Teknologi Surabaya.

Fitrianah D, Sucahyo YG. 2010. Audit sistem informasi/ teknologi informasi dengan kerangka kerja COBIT untuk evaluasi manajemen teknologi informasi di Universitas XYZ. Jurnal Sistem Informasi MTI-UI 4(1): 37-46. https://doi. org/10.21609/jsi.v4i1.243.

Grembergen WV. 2000. The balanced Scorecard and IT governance. Information System Control Journal 2(1): 40-43.

Guldentops E. 2003. Maturity measurement - first the Purpose, then the method. Information Systems Control Journal 4: 15-16.

Hallikainen P dan Chen L. 2005. A holistic framework on information systems evaluation with a case analysis. The Electronic Journal Information Systems Evaluation 9(2): 57-64.

Lee DH, Lee SM, Olson DL dan Chung SH. 2010. The effect of organizational support on ERP implementation. Emerald Industrial Management \& Data Systems 110(2): 269-283. https://doi.org/10.1108/02635571011020340.

Pederiva A. 2003. The COBIT maturity model in a vendor evaluation case. Information System Control Journal 3(1): 1-4.

Purnomo LHD. 2010. Perancangan Model Tata Kelola Ketersediaan Layanan TI Menggunakan Framework COBIT pada BPK-RI [Tesis]. Surabaya: Institut Teknologi Surabaya.

Purwanto. 2010. Evaluasi tata kelola IT menggunakan kerangka kerja COBIT dalam mendukung layanan sistem informasi akademi studi kasus: Universitas Budi Luhur. Jurnal Telematika MKOM 2(1): 41-52.

Suhardi SN. 2011. Evaluasi Kematangan Pengelolaan TI pada PT. Multi Garmenjaya Surabaya dengan Pendekatan COBIT [tesis]. Surabaya: Institut Teknologi Surabaya.

Tsai WH, Lee PL, Chen SP, Hsu W dan Lin TW. 2009. A study of the selection criteria for enterprise resource planning systems. International Journal Business and Systems Research 3(4): 456-480. https://doi.org/10.1504/IJBSR.2009.027200.

Widuri, Retnaningtyas, 2010, Ketidakpastian tugas sebagai variabel moderator terhadap hubungan antara pemanfaatan teknologi informasi dan kepuasan pengguna pada end-user computing, Jurnal Akuntansi dan Keuangan 12(1): 41-52. 